\title{
THE SEASONAL DYNAMICS OF PHYTOPLANKTON AND WATER QUALITY IN THE PRUT RIVER LOWER SECTOR
}

\section{Laurentia Ungureanu, Daria Tumanova*, Grigore Ungureanu}

\author{
Institute of Zoology, Chisinau, Republic of Moldova \\ *e-mail: dariatumanova@gmail.com
}

\begin{abstract}
The article presents the results on qualitative and quantitative indicators of phytoplankton of the Prut River lower sector within the Republic of Moldova in 2018-2020. In phytoplankton compositions 72 species were identified. Seasonal and long-term patterns of phytoplankton development have been established in Prut River lower sector. The numbers of phytoplankton changed within the limits 1,06 to $20,32 \mathrm{mln}$. cell/1, with biomass $1,23-21,64 \mathrm{~g} / \mathrm{m} 3$. The values of saprobic indexes, estimated on the basis of species-indicators (52 species) from phytoplankton composition, which are in proportion of $58 \%$ typically $\beta$-mezosaprobic, confirm the following: the water quality of lower Prut River sector in the period 2018-2020 was satisfactory for the development of phytoplankton and was attributed mainly to II-III (good-moderately polluted) quality classes.
\end{abstract}

\section{Introduction}

The Prut River is the second longest and the last major tributary of the Danube, with its confluence located just upstream of the Danube Delta [7]. The study of phytoplankton development and water quality of lower Prut river sector are of particular importance in terms of eutrophication and continuous pollution. Photoautotrophic plankton is the major primary producer of organic carbon in the waters. Phytoplankton composition and biomass provides an integrated view on water-quality conditions, an indication of eutrophication. Reaction of the phytoplankton to the natural and anthropogenic factors is closely connected with changes in algae abundance, biomass and species composition and it is a reliable indicator of the aquatic ecosystems $[4,5]$.

\section{Material and methods}

Researches of phytoplankton were carried out seasonal during 2018-2020 from lower Prut River sector (Cahul, Caslita-Prut and Giurgiulesti sampling points) in the research of the Laboratory of Hydrobiology and Ecotoxicology of the Institute of Zoology. Algae species identification was performed using the microscope MIKMED-2 (LOMO) and identifying keys [2]. To estimate the trophic dynamics seasonal and annual values of biomass were used. Sampling and analysis of phytoplankton was carried out by conventional hydrobiological methods $[1-3,6]$.

\section{Results and discussion}

In phytoplankton compositions of the lower Prut River sector during 2018-2020, 72 species were identified, and represented by 5 taxonomical groups: Cyanophyta-8, Bacillariophyta-38, Chrysophyta-2, Euglenophyta-8, Chlorophyta-16 (Chlorococcophyceae-14, Volvocineae-1, Desmidiales-1). It was found that the phytoplankton species of the following groups predominated: Cyanophyta, Bacillariophyta and Chlorophyta. (Tab.1.). The basis of the floristic diversity of lower Prut River sector consists of such species as: Aphanizomenon flos-aquae (L.) 
Ralfs, Oscillatoria lacustris (Kleb.), from blue-green algae, Cyclotella kuetzingiana Thw., Navicula cryptocephala Kutz., Synedra acus Kutz., Synedra ulna (Nitz.) from diatoms algae, Monoraphidium Komarkovae (Nyg.), Monoraphidium contortum Thur. and Scenedesmus quadricauda Turp. from green algae. The quantitative parameters of phytoplankton vary widely in seasonal and annual aspect.

Table 1. The number of planktonic algae found in the lower Prut river sector during 2018-2020

\begin{tabular}{|l|c|c|c|}
\hline \multicolumn{1}{|c|}{ Algal groups } & Cahul & Caslita-Prut & Giurgiulesti \\
\hline Cyanophyta (Cyanobacteria) & 3 & 4 & 7 \\
\hline Bacillariophyta & 27 & 26 & 34 \\
\hline Chrysophyta & - & 2 & 4 \\
\hline Euglenophyta & 2 & 7 & 9 \\
\hline Chlorophyta: & & & - \\
\hline Chlorococcophyceae & 7 & 11 & - \\
\hline Volvocineae & - & 1 & $\mathbf{5 5}$ \\
\hline Desmidiales & - & 1 & $\mathbf{5 2}$ \\
\hline Total & $\mathbf{3 9}$ & & \\
\hline The & & & \\
\hline
\end{tabular}

The number of phytoplankton species in lower Prut River sector was in limits 1,06-20,32 $\mathrm{mln}$. cell/1, and biomass 1-21,94 g/m3 in spring, 1,61-18,68 mln. cell/1, with biomass 1,9-10,36 $\mathrm{g} / \mathrm{m} 3$ in the summer, 1,36-6,88 mln. cell/1, and biomass 1,23-6,44 g/m3 during autumn (Fig.1.).

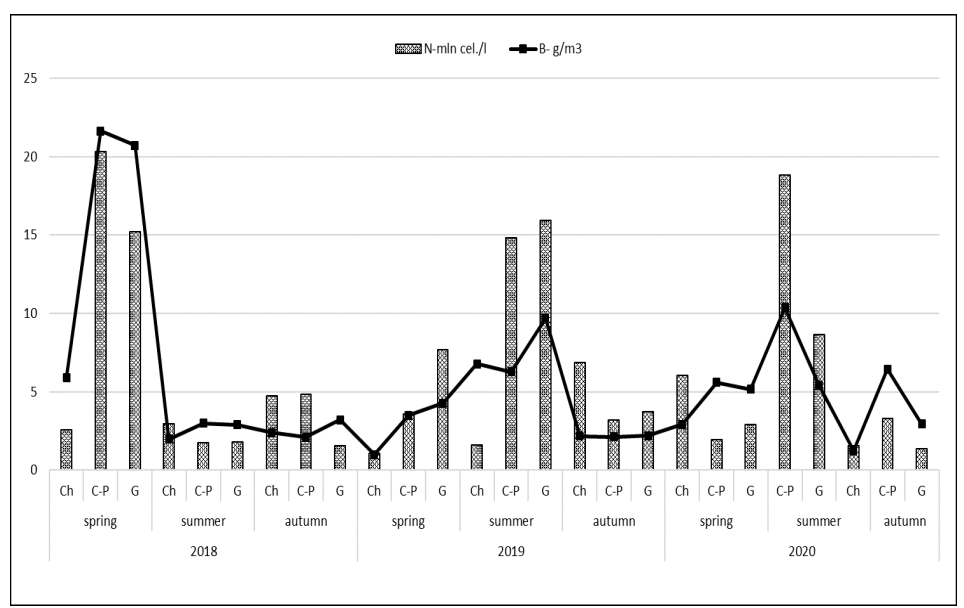

Figure 1. Dynamics of quantity (N-mln cell/l) and biomass $(\mathrm{B}-\mathrm{g} / \mathrm{m} 3)$ of phytoplankton in the lower Prut river sector (C-Cahul, C-P - Caslita-Prut and G-Giurgiulesti sampling points) during 2018-2020.

The highest values of phytoplankton species number and their biomass were attested at Caslita-Prut and Giurgiulesti during spring 2018 and at Caslita -Prut sampling points during summer time 2020. In lower sector the preponderance of Cyanophyta, Bacillariophyta and Chlorophyta in the forming of the number of algae species was attested. Species of algae which are growing in large quantities were represented by: Aphanizomenon flos-aquae (L.) Ralfs, Os- 
cillatoria planctonica (Wolocz.), Oscillatoria lacustris (Kleb.), Synechocistys aquatilis (Sanv.), Asterionella formosa Hass., Nitzschia acicularis W.Sm., Monoraphidium contortum Thur., Scenedesmus falctus Chod.

The main part in the formation of phytoplankton biomass was Bacillariophyta algae: Cocconeis placentula (Ehr.), Cymatopleura solea (Breb.) W.Sm., Cyclotella Kuetzingiana Thw., Nitzschia sigmoidea (Ehr.) W.Sm., Gyrosigma acuminatum (Kutz.), Rhoicosphenia curvata (Kutz.), Synedra ulna (Nitzh.)Ehr., Surirella robusta Ehr. v.splendida and mostly in summer time presented by Euglenophyta species: Trachelomonas hispida (Perty) Stein., Euglena polymorpha Dang., Lepocinclis fusiformis (Lemm), Phacus pleuronectes (Mull.).

For the estimation of trophicity of lower Prut river sector, according to the criteria of classification and trophicity categories of continental aquatic ecosystems [2], were used the seasonal and multiannual values of phytoplankton biomass. Thus, according to the values of phytoplankton biomass, which in 2018-2020 varied within the limits of 1,00-21,64 g/ m3, the lower Prut River sector was attributed to the category of "eutrophic" trophicity, periodically "polytrophic" (Fig.1.).

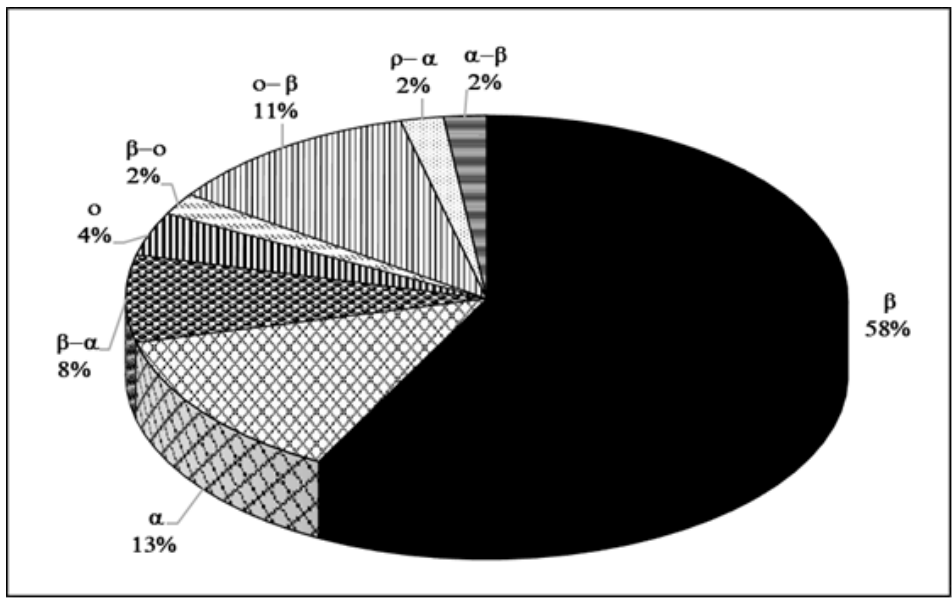

Figure 2. Distribution of phytoplankton indicator types according to the zone of saprobity in lower Prut river sector 2018-2020

From whole number of species of algae, identified in Prut river lower sector (72 species and varieties of phytoplankton) 52 were indicators of water saprobity, the most frequently met, were the following: Aphanizomenon flos-aquae (L.) Ralfs, Asterionella formosa Hass., Cyclotella Kuetzingiana Thw., Gomphonema olivaceum (Lyngb.), Hantyschia amphyoxis (Grun.), Navicula gracilis (Ehr.), Navicula cryptocephala (Kutz.), Surirella robusta (Ehr.), Euglena polymorpha(Dang.)., Trachelomonas hispida (Perty) Stein., Scenedesmus quadricauda Turp. more than $58 \%$ of them were $\beta$-mesosaprobe species. $\alpha$-mesosaprobe species made $13 \%$, the most frequent of which were: Nitzschia acicularis W.Sm., Nitzschia palea (Kutz.), Euglena polymorpha Dang., Closterium acerosum (Ehr.); O- $\beta$ mesosaprobe species were 11 $\%$, the most frequent of which were the species: Anabaena spiroides (Lemm.), Epithemia ze- 
bra (Ehr.), Fragilaria capucina (Desm.), Melosira italica (Ehr.); species $\beta$ - $\alpha$-mesosaprobic (8\%) were represented by: Merismopedia tenuissima (Lemm), Cymatopleura solea (Breb.), Navicula cincta (Pant.), Navicula hungarica v. capitata (Grun.); species o-oligosaprobic (4\%) were presented by: Dinobryon sertularia (Ehr.), Ophiocitium capitatum (Woll.); and species: $\beta$-O-mesosaprobic were accoumting for $6 \%$ (Navicula gracilis (Ehr.)), $\alpha-\beta$ mesosaprobic (Cyclotella meneghiniana (Kutz)), $\rho-\alpha$ - mesosaprobic (Chlorella vulgaris (Beier.)). (Fig.2.). Species with preference to the $\chi$ - xenosaprobe zone have not attested in Prut river lower sector, these however beingmet in the previous years $[4,5]$.

The saprobic index values were established within the limits 1,98-2,3 in spring time, 1,922,34 in summer and 1,9-2,3 at lower Prut river sector, with high values at Cahul sampling point. According to saprobic value indices, the water quality of lower Prut river sector sector was satisfactory for the development of phytoplankton and was attributed mainly to II-III (good-moderately polluted) quality classes.

\section{Conclusions}

The basis of the floristic diversity of the lower Prut river sector consists of groups: Bacillariophyta, Cyanophyta, Chlorophyta, Euglenophyta and Chrysophyta.

Higher values of quantitative phytoplankton parameters were recorded during the spring and summer periods. In most cases the phytoplankton biomass values referred to the trophic category "eutrophic" sometimes "polytrophic".

According to saprobic index values indices, the water quality of lower Prut river sector was satisfactory for the development of phytoplankton and was attributed mainly to II-III (good-moderately polluted) quality classes.

Acknowledgements. The study was carried out in the framework of the project BSB27 "Black Sea Basin interdisciplinary cooperation network for sustainable joint monitoring of environmental toxicants migration, improved evaluation of ecological state and human health impact of harmful substances, and public exposure prevention - Monitox, funded by the Joint Operational Programme Black Sea Basin 2014-2020. The content of this publication is the sole responsibility of the authors and in no way reflect the views of the European Union. Also, investigations were conducted within the state projects AQUASYS (2015-2019) and AQUABIO (2020-2023).

\section{Bibliography}

1. Ungureanu L., Tumanova D. Sampling of fitoplankton. În Ghid de prelivare a probelor hidrochimice şi hidrobiologice=Hydrochemical and hydrobiological sampling guidance. Progr. Operaţional Comun România-Ucraina-Republica Moldova 2007-2013; Chişinău 2015; p.12-14

2. Ungureanu L., Tumanova D., Ungureanu G. În îndrumar metodic: Monitoringul calităţii apei şi evaluarea stării ecologice a ecosistemelor acvatice. / Acad. de Ştiinţe a Moldovei, Inst.de Zoologie, Univ. Acad. de Ştiinţe a Moldovei Chişinău 2015; p.41-45

3. Ungureanu L.; Tumanova D.; Ungureanu G. Capitol V: Phytoplankton. Primary prodaction of phytoplankton and destruction of organic matter. In: Guidance on the Monitoring of Water Quality and Assessment of the Ecological Status of Aquatic Ecosystems. Chişinau 2020; pp. $49-52$ 
4. Ungureanu L.; Zubcov E.; Tumanova D.; Bagrin N.; Ciorba P.; Ungureanu G. Factorii determinanţi ai dezvoltării fitoplanctonului în râul Prut.În: Buletinul Academiei de Ştiinţe a Moldovei. Ştiinţele vieţii. Articole de fond. Chişinău 2020, N2 (341) p. 39-46 ISSN 1857-064X.

5. Tumanova D.; Ungureanu L.; Ene A.; Teodorof L. Phytoplankton state and water quality in the Lower Prut River. In materiales: "Environmental Toxicants in Freshwater and Marine Ecosystems in the Black Sea Basin" September 8th-11th, 2020 Kavala, Greece. pp. 73-74

6. Regulament cu privire la cerinţele de calitate a mediului pentru apele de suprafaţă. Anexa 1. publicat: 22.11.2013 în Monitorul Oficial Nr.262-267, art. Nr.1006, 2013, p. 32-39.

7. https://www.icpdr.org/main/danube-basin/river-basin 